\title{
Video Article \\ Design, Synthesis, and Photochemical Properties of Clickable Caged Compounds
}

\author{
Akinobu Z. Suzuki ${ }^{1}$, Yukiko Shiraishi ${ }^{1}$, Hanami Aoki ${ }^{1}$, Hirona Sasaki ${ }^{1}$, Rei Watahiki $^{1}$, Toshiaki Furuta $^{1}$ \\ ${ }^{1}$ Department of Biomolecular Science, Faculty of Science, Toho University
}

Correspondence to: Toshiaki Furuta at furuta@biomol.sci.toho-u.ac.jp

URL: https://www.jove.com/video/60021

DOI: doi:10.3791/60021

Keywords: Chemistry, Issue 152, caged compounds, synthesis, photochemistry, click chemistry, prodrug, chemical biology, chemical probes

Date Published: $10 / 15 / 2019$

Citation: Suzuki, A.Z., Shiraishi, Y., Aoki, H., Sasaki, H., Watahiki, R., Furuta, T. Design, Synthesis, and Photochemical Properties of Clickable Caged Compounds. J. Vis. Exp. (152), e60021, doi:10.3791/60021 (2019).

\section{Abstract}

Caged compounds enable the photo-mediated manipulation of the cell physiology with high spatiotemporal resolution. However, the limited structural diversity of currently available caging groups and the difficulties in synthetic modification without sacrificing their photolysis efficiencies are obstacles to expanding the repertoire of caged compounds for live cell applications. As the chemical modification of coumarin-type photocaging groups is a promising approach for the preparation of caged compounds with diverse physical and chemical properties, we report a method for the synthesis of clickable caged compounds that can be modified easily with various functional units via the copper(I)-catalyzed Huisgen cyclization. The modular platform molecule contains a (6-bromo-7-hydroxycoumarin-4-yl)methyl (Bhc) group as a photo-caging group, which exhibits a high photolysis efficiency compared to those of the conventional 2-nitrobenzyls. General procedures for the preparation of clickable caged compounds containing amines, alcohols, and carboxylates are presented. Additional properties such as the water solubility and cell targeting ability can be readily incorporated into clickable caged compounds. Furthermore, the physical and photochemical properties, including the photolysis quantum yield, were measured and were found to be superior to those of the corresponding Bhc caged compounds. The described protocol could therefore be considered a potential solution for the lack of structural diversity in the available caged compounds.

\section{Video Link}

The video component of this article can be found at https://www.jove.com/video/60021/

\section{Introduction}

Caged compounds are designed synthetic molecules whose original functions are temporally masked by covalently attached photo-removable protecting groups. Interestingly, caged compounds of biologically relevant molecules provide an indispensable method for the spatiotemporal control of the cellular physiology ${ }^{1,2,3,4,5,6}$. In 1977, Engels and Schlaeger reported the 2-nitrobenzyl ester of cAMP as a membrane permeable and photolabile derivative of cAMP ${ }^{7}$. The following year, Kaplan reported the 1-(2-nitrophenyl)ethyl ester of ATP (NPE-ATP) and named this compound "caged" ATP ${ }^{8}$. Since then, a range of photochemically removable protecting groups such as 2 -nitrobenzyls, $p$-hydroxyphenacyls ${ }^{9}, 2$ (2-nitrophenyl)ethyls ${ }^{10,11}$, 7-nitroindolin-1-yls ${ }^{12,13}$, and (coumarin-4-yl)methyls ${ }^{14,15,16}$ have been used for the preparation of caged compounds.

The synthesis of caged compounds with desirable additional properties such as membrane permeability, water solubility, and cellular targeting ability would be expected to facilitate cell biological applications. Since the physical and photochemical properties of these molecules depend primarily on the chemical structure of the photochemically removable protecting groups used to prepare them, a diverse repertoire of photocaging groups is required. However, the structural diversity of currently available caging groups that exhibit high photolysis efficiencies is limited. This could be an obstacle to increasing the use of caged compounds.

To address this issue, the repertoire of photo-caging groups has been expanded by the chemical modification of existing photoremovable protecting groups or the design of new photolabile chromophores with superior photophysical and photochemical properties. Examples include nitrodibenzofuran (NDBF) ${ }^{17},\left[3-\left(4,5\right.\right.$-dimethoxy-2-nitrophenyl)-2-butyl] (DMNPB) ${ }^{18,19}$, a calcium-sensitive 2-nitrobenzyl photocage ${ }^{20}$, substituted coumarinylmethyls (DEAC45021 ${ }^{21}$, DEAdcCM ${ }^{22}, 7$-azetidinyl-4-methylcoumarin ${ }^{23}$, and styryl coumarins ${ }^{24}$ ), cyanine derivatives $\left(\mathrm{CyEt}\right.$-pan) ${ }^{25}$, and BODIPY derivatives ${ }^{26,27}$.

In addition, we previously developed the (6-bromo-7-hydroxycoumarin-4-yl)methyl (Bhc) group and successfully synthesized various caged compounds of neurotransmitters ${ }^{28}$, second messengers ${ }^{29,30}$, and oligonucleotides ${ }^{31,32,33}$ exhibiting large one- and two-photon excitation crosssections. If additional properties can be installed easily into the caging groups without compromising their photosensitivity, then the repertoire of caged compounds can be expanded ${ }^{34,35,36,37,38,39}$. We therefore designed modular caged compounds that comprise three parts, namely the Bhc group as a photo-responsive core, chemical handles for the installation of additional functionalities, and the molecules that are to be masked ${ }^{40,41}$

Thus, this article provides a practical method for the preparation of caged compounds of biologically relevant molecules. The present protocol describes methods for the preparation of a clickable platform for photo-caging groups, the introduction of additional functionalities to expand 
the repertoire of caged compounds, the measurement of their physical and photochemical properties, and the cell-type selective targeting of a clickable caged compound for further cellular application.

Protocol

\section{Synthesis of the modular caging paBhc group for clickable caged compounds ${ }^{28,41}$}

1. Preparation of (6-bromo-7-hydroxycoumarin-4-yl)methyl chloride (Bhc- $\left.\mathrm{CH}_{2} \mathrm{Cl}\right)$

1. Place 4-bromoresorcinol $(9.742 \mathrm{~g}, 51.5 \mathrm{mmol})$ in a $100 \mathrm{~mL}$ round-bottomed flask equipped with a stirrer bar.

2. Add conc. $\mathrm{H}_{2} \mathrm{SO}_{4}(98 \%, 30 \mathrm{~mL})$ to the flask and stir the mixture to dissolve.

3. Add ethyl 4-chloroacetoacetate $(10 \mathrm{~mL}, 74 \mathrm{mmol})$ dropwise.

4. Continue stirring the mixture at ambient temperature for 5 days.

5. Separately, place crushed ice cubes $(\sim 200 \mathrm{~mL})$ in a $500 \mathrm{~mL}$ Erlenmeyer flask.

6. Pour the reaction mixture into the ice and stir vigorously for $30 \mathrm{~min}$ until a finely powdered precipitate is obtained.

7. Collect the precipitate via vacuum filtration. Wash the light brown precipitate with water five times.

8. Dry the precipitate under vacuum overnight to yield $\mathrm{BhcCH}_{2} \mathrm{Cl}$ as a light brown powder $(13.57 \mathrm{~g}, 46.9 \mathrm{mmol})$.

2. Preparation of (6-bromo-7-hydroxycoumarin-4-yl)methanol $\left(\mathrm{BhcCH}_{2} \mathrm{OH}\right)$

1. Place the prepared $\mathrm{BhcCH}_{2} \mathrm{Cl}(1.1440 \mathrm{~g}, 3.95 \mathrm{mmol})$ and $1 \mathrm{M} \mathrm{HCl}(300 \mathrm{~mL})$ in a $1 \mathrm{~L}$ round-bottomed flask equipped with a Dimroth condenser. Stir the mixture at $140{ }^{\circ} \mathrm{C}$ for 5 days. After this time, cool the mixture to ambient temperature.

2. Remove the water from the reaction by rotary evaporation under vacuum to yield $\mathrm{BhcCH}_{2} \mathrm{OH}(1)$ as a light brown powder (1.0359 g, $3.82 \mathrm{mmol}, 97 \%$ yield).

NOTE: The use of $250 \mathrm{~mL}$ of $1 \mathrm{M} \mathrm{HCl}$ per $1 \mathrm{~g}$ of $\mathrm{BhcCH}_{2} \mathrm{Cl}$ gives a satisfactory result.

3. Preparation of $\mathrm{paBhcCH}_{2} \mathrm{OH}(2)$ via the Mannich reaction

1. Place paraformaldehyde $(446.4 \mathrm{mg}, 14.9 \mathrm{mmol})$ in a $50 \mathrm{~mL}$ round-bottomed flask. Add anhydrous ethanol $(5 \mathrm{~mL})$ and $\mathrm{N}$-methylpropargylamine $(1.25 \mathrm{~mL}, 14.8 \mathrm{mmol})$ to the flask.

2. Stir the mixture at ambient temperature for $1 \mathrm{~h}$ under an $\mathrm{Ar}$ atmosphere.

3. Add $\mathrm{BhcCH}_{2} \mathrm{OH}(1)(1.367 \mathrm{~g}, 5.04 \mathrm{mmol})$ to the flask. Heat the mixture to $80{ }^{\circ} \mathrm{C}$ with a block heater apparatus, and continue stirring the mixture at $80^{\circ} \mathrm{C}$ for $2 \mathrm{~h}$ under an $\mathrm{Ar}$ atmosphere.

4. Stop the block heater and cool the reaction mixture to room temperature.

5. Collect the resulting light brown-yellow precipitate by vacuum filtration. Wash the precipitate twice with a small amount of anhydrous ethanol ( $1 \mathrm{~mL}$ each time).

6. Remove the excess ethanol under vacuum to yield $\mathrm{paBhcCH}_{2} \mathrm{OH}(2)(1.393 \mathrm{~g}, 3.96 \mathrm{mmol})$.

\section{Preparation of clickable caged compounds}

NOTE: The following procedures can be applied to the preparation of other clickable caged compounds containing hydroxyl, amino, and carboxylate functional groups.

1. General Procedure 1: Preparation of a clickable caged amine

1. Place paBhcCH $\mathrm{OH}_{2} \mathrm{O}$ (2) $(709.6 \mathrm{mg}, 2.02 \mathrm{mmol})$ and $N, N$ '-carbonyl diimidazole (CDI, $\left.397.6 \mathrm{mg}, 2.45 \mathrm{mmol}\right)$ in a $30 \mathrm{~mL}$ round-bottomed flask. Add dry $\mathrm{CH}_{2} \mathrm{Cl}_{2}(6 \mathrm{~mL})$ and stir the solution at ambient temperature for $1 \mathrm{~h}$.

2. Add 4-dimethylaminopyridine (4-DMAP, $324.8 \mathrm{mg}, 2.66 \mathrm{mmol}$ ) and tert-butyl (6-aminohexyl)carbamate $(533.1 \mathrm{mg}, 2.46 \mathrm{mmol})$. Stir the solution at ambient temperature for $3 \mathrm{~h}$.

3. Remove the solvent and other volatile materials using a rotary evaporator under vacuum. Purify the residue directly using silica gel flash column chromatography.

2. General Procedure 2: Preparation of a clickable caged alcohol

1. Place paclitaxel (PTX, $48.7 \mathrm{mg}, 0.057 \mathrm{mmol}$ ) in a $30 \mathrm{~mL}$ round-bottomed flask equipped with a three-way stopcock and an Ar balloon. Add dry $\mathrm{CH}_{2} \mathrm{Cl}_{2}(1 \mathrm{~mL}), 4$-DMAP $(17.1 \mathrm{mg}, 0.14 \mathrm{mmol})$, and 4-nitrophenyl chloroformate $(26.0 \mathrm{mg}, 0.13 \mathrm{mmol})$.

2. Stir the solution at ambient temperature for $2.5 \mathrm{~h}$ under an $\mathrm{Ar}$ atmosphere.

3. Add 4-DMAP (15.7 mg, $0.13 \mathrm{mmol})$ and $\mathrm{paBhcCH}_{2} \mathrm{OH}(2)(39.1 \mathrm{mg}, 0.111 \mathrm{mmol})$ to the solution. Continue stirring the mixture at ambient temperature for $17 \mathrm{~h}$.

4. Add $\mathrm{CHCl}_{3}(10 \mathrm{~mL})$ and $15 \%$ aqueous $\mathrm{NaHCO}_{3}(5 \mathrm{~mL})$ to the mixture. Stir the mixture vigorously for approximately 3 min. Remove the aqueous layer with a pipette.

5. Add $0.5 \mathrm{M}$ citric acid $(5 \mathrm{~mL})$ to the flask containing the organic layer. Stir the mixture and remove the aqueous layer as above.

6. Separate the organic layer using a phase separation column. Remove the solvents with a rotary evaporator under vacuum. Purify the product using standard silica gel flash column chromatography.

3. General Procedure 3: Preparation of a clickable caged carboxylic acid

1. Dissolve arachidonic acid $\left.(33.0 \mu \mathrm{L}, 0.100 \mathrm{mmol}), \mathrm{paBhcCH} \mathrm{OH}_{2} \mathrm{O}\right)(39.6 \mathrm{mg}, 0.112 \mathrm{mmol})$, and 4-DMAP $(14.1 \mathrm{mg}, 0.115 \mathrm{mmol})$ in dry $\mathrm{CH}_{2} \mathrm{Cl}_{2}\left(2 \mathrm{~mL}\right.$ ). Add $N, N^{\prime}$-diisopropylcarbodiimide (DIPC, $17.0 \mu \mathrm{L}, 0.110 \mathrm{mmol}$ ) and stir the solution at ambient temperature for $140 \mathrm{~min}$

2. Remove the solvent under vacuum. Purify the residue directly using silica gel flash column chromatography. 


\section{Installation of a functional unit into the clickable caged compounds}

1. Dissolve copper(II) sulfate pentahydrate $(249 \mathrm{mg})$ in ion-exchanged water (IEW, $10 \mathrm{~mL}$ ) to give a $0.1 \mathrm{M} \mathrm{CuSO}_{4}$ solution.

2. Dissolve 2'-paBhcmoc-PTX ( $8.0 \mathrm{mg}, 6.5 \mu \mathrm{mol})$, tris(3-hydroxypropyltriazolylmethyl)amine (THPTA, $17.5 \mathrm{mg}, 40.3 \mu \mathrm{mol})$, sodium l-ascorbate (162.4 mg, $0.825 \mathrm{mmol})$, and 15-chloro-3,6,9-trioxapentadecyl azide $(3.1 \mathrm{mg}, 11 \mu \mathrm{mol})$ in a mixed solvent of $0.1 \mathrm{M}$ phosphate buffer $(2.5 \mathrm{~mL}$, $\mathrm{pH} 7.2$ ) and dimethyl sulfoxide (DMSO, $0.5 \mathrm{~mL})$.

3. Add the $0.1 \mathrm{M} \mathrm{CuSO}_{4}$ solution $(81.2 \mu \mathrm{L}, 8.1 \mu \mathrm{mol})$ to the reaction mixture. Stir the mixture at ambient temperature for $80 \mathrm{~min}$. Monitor the progress of the reaction using high-performance liquid chromatography (HPLC).

4. Dissolve the precipitates by adding a $75 \%$ acetonitrile/water solution $(3.5 \mathrm{~mL})$. Apply the resulting solution directly to the semi-preparative HPLC system to purify the desired product.

NOTE: Solubilization of the reaction mixture by the addition of tert-butanol can accelerate the progression of the reaction.

\section{Photolytic uncaging reaction of the caged compounds}

\section{Preparation of the stock solutions}

1. Dissolve the desired caged compound $(5 \mu \mathrm{mol})$ in DMSO $(500 \mu \mathrm{L})$ to prepare a $10 \mathrm{mM}$ stock solution. Dispense an aliquot of each solution $(10 \mu \mathrm{L})$ into a $1.5 \mathrm{~mL}$ microcentrifuge tube and store in a freezer $\left(-20{ }^{\circ} \mathrm{C}\right)$ until just before use.

2. $6 \mathrm{mM} \mathrm{K}_{3}\left[\mathrm{Fe}\left(\mathrm{C}_{2} \mathrm{O}_{4}\right)_{3}\right](100 \mathrm{~mL})$ : Dissolve recrystallized potassium ferrioxalate $(0.295 \mathrm{~g}, 0.675 \mathrm{mmol})$ in $80 \mathrm{~mL}$ of water. Add $0.5 \mathrm{M}$ $\mathrm{H}_{2} \mathrm{SO}_{4}(10 \mathrm{~mL})$ and an appropriate amount of IEW to make up the volume to $100 \mathrm{~mL}$.

NOTE: Potassium ferrioxalate should be purified via recrystallization from hot water and stored in the dark. Recrystallized potassium ferrioxalate is obtained as the trihydrate; therefore, its formula is $\mathrm{K}_{3}\left[\mathrm{Fe}\left(\mathrm{C}_{2} \mathrm{O}_{4}\right)_{3}\right] \cdot 3 \mathrm{H}_{2} \mathrm{O}$ and a formula weight of 491.24 should be considered during preparation of the stock solution. Check the purity of the $6 \mathrm{mM}$ solution by measuring its absorption at $510 \mathrm{~nm}$. If the absorbance is $<0.02$, it is suitable for use in the experiment.

3. $0.1 \%$ Buffer-phen $(30 \mathrm{~mL})$ : Dissolve $\mathrm{NaOAc} \cdot 3 \mathrm{H}_{2} \mathrm{O}(7.35 \mathrm{~g}), 1,10$-phenanthroline (phen) $\cdot \mathrm{H}_{2} \mathrm{O}(30 \mathrm{mg})$, and conc. $\mathrm{H}_{2} \mathrm{SO}_{4}(0.9 \mathrm{~mL})$ in IEW $(20 \mathrm{~mL})$. Add IEW to make up the volume to $30 \mathrm{~mL}$.

NOTE: The solution contains $1.8 \mathrm{M} \mathrm{NaOAc}, 0.54 \mathrm{M} \mathrm{H}_{2} \mathrm{SO}_{4}$, and $0.1 \%$ 1,10-phenanthroline.

\section{Measurement of the number of photons using ferrioxalate actinometry}

1. Place $6 \mathrm{mM} \mathrm{K}_{3}\left[\mathrm{Fe}\left(\mathrm{C}_{2} \mathrm{O}_{4}\right)_{3}\right]\left(\mathrm{V}_{1} \mathrm{~L}\right)$ in a quartz cuvette. Irradiate the solution with $350 \mathrm{~nm}$ light for $5 \mathrm{~s}$.

2. Transfer the irradiated solution to a Pyrex cuvette with an $I[\mathrm{~cm}]$ path length.

3. Add $0.1 \%$ Buffer-phen $\left(V_{2} L\right)$ to the irradiated sample solution and mix well by pipetting. Measure the absorbance of the sample at 510 $\mathrm{nm}$. Calculate the average absorption change per unit time $\left(\Delta \mathrm{A}_{510}\left[\mathrm{~s}^{-1}\right]\right)$.

4. Calculate the number of moles of generated $\mathrm{Fe}^{2+}$ ions per unit time according to the following equation: $\mathrm{nFe} e^{2+}\left[\mathrm{mol} \mathrm{s}^{-1}\right]=\left(\left(V_{1}+V_{2}\right)[\mathrm{L}] \times \Delta \mathrm{A}_{510}\left[\mathrm{~s}^{-1}\right]\right) /\left(I[\mathrm{~cm}] \times \varepsilon_{510}\left[\mathrm{~L} \mathrm{~mol}^{-1} \mathrm{~cm}^{-1}\right]\right)$, where $\left(V_{1}+V_{2}\right)$ is the volume of the sample for the absorption measurement, $l$ is the optical path length of the cuvette, and $\varepsilon_{510}$ is the molar absorptivity of the $\mathrm{Fe}^{2+}$-phen complex at $510 \mathrm{~nm}$.

NOTE: In the typical experimental conditions, values of $V_{1}=2.0 \times 10^{-3} \mathrm{~L}, V_{2}=0.33 \times 10^{-3} \mathrm{~L}, I=1.0 \mathrm{~cm}$, and $\varepsilon_{510}=1.1 \times 10^{4} \mathrm{~L} \mathrm{~mol}{ }^{-1}$ $\mathrm{cm}^{-1}$ were used.

5. Calculate the number of moles of photons that reach the sample $\left(I_{0}\right)$ using the following formula:

$I_{0}\left[\right.$ einstein $\left.\mathrm{cm}^{-2} \mathrm{~s}^{-1}\right]=\mathrm{nFe}^{2+} / \Phi_{350}$

where $\Phi_{350}$ is the quantum efficiency of photoreduction of the ferrioxalate at $350 \mathrm{~nm}$.

NOTE: Although the quantum efficiency of the potassium ferrioxalate actinometer at $350 \mathrm{~nm}$ is not reported, the reported value of $1.25^{42}$ at $358 \mathrm{~nm}$ was employed.

3. Quantum efficiency measurements at $350 \mathrm{~nm}$

1. Dilute the sample stock solution (in DMSO, $10 \mu \mathrm{L}$ ) with $\mathrm{K}-\mathrm{MOPS}$ buffer $(\mathrm{pH} \mathrm{7.2,10} \mathrm{mL)}$ ) to give a $10 \mu \mathrm{M}$ solution in $\mathrm{K}-\mathrm{MOPS}$ containing $0.1 \%$ DMSO.

NOTE: K-MOPS buffer consisted of $100 \mathrm{mM} \mathrm{KCl}$ and $10 \mathrm{mM} 3-(\mathrm{N}$-morpholino)propanesulfonic acid (Mops) titrated to $\mathrm{pH} 7.2 \mathrm{with} \mathrm{KOH}$.

2. Transfer an aliquot of the solution $\left(V_{1} \mathrm{~L}\right)$ into the same cuvette used in the photoreaction of the chemical actinometer. Irradiate the sample solution using the same setup as described in step 4.2.1.

3. Remove an aliquot $(50 \mu \mathrm{L})$ from the irradiated solution periodically and analyze using HPLC.

4. Determine the irradiation time, in seconds, in which $90 \%$ of the starting material reacted $\left(t_{90 \%}\right)$ by fitting plots of the time-dependent disappearance of the starting material.

NOTE: The absorbance of the irradiated sample must be maintained at $<0.1$ so that the inner filtering of the radiation can be neglected. It is desirable that the photolytic consumption of the starting material can be approximated by single-exponential decay so that there is no undesired secondary effect that interferes with the photolysis process.

5. Calculate the quantum yield of disappearance $\left(\Phi_{\text {dis }}\right)$ using the following equation ${ }^{28}$ :

$\Phi_{\text {dis }}=1 /\left(t_{90 \%} \times I_{0} \times \sigma_{350}\right)$

where $t_{90 \%}$ [s] is the irradiation time in which $90 \%$ of the starting material was consumed, $I_{0}$ [einstein $\mathrm{cm}^{-2} \mathrm{~s}^{-1}$ ] is the number of moles of photons, and $\sigma_{350}\left[\mathrm{~cm}^{2} \mathrm{~mol}^{-1}\right]$ is the decadic extinction coefficient of the sample at $350 \mathrm{~nm}$.

NOTE: $\sigma_{350}\left[\mathrm{~cm}^{2} \mathrm{~mol}^{-1}\right]=10^{3} \varepsilon_{350}\left[\mathrm{M}^{-1} \mathrm{~cm}^{-1}\right]$. 


\section{Targeting of a clickable caged compound with a HaloTag ligand}

NOTE: Prior to use, maintain the HeLa cells in Dulbecco's modified Eagle medium (DMEM, low glucose, sodium pyruvate, I-glutamine) supplemented with $10 \%$ fetal bovine serum (FBS) containing $1 \%$ antibiotics (streptomycin sulfate, penicillin $\mathrm{G}$, and amphotericin) at $37{ }^{\circ} \mathrm{C}$ and $5 \% \mathrm{CO}_{2}$.

1. Remove the medium and trypsinize the cells by treating with trypsin-ethylenediaminetetraacetic acid (EDTA, $1 \mathrm{~mL}$ ) at $37^{\circ} \mathrm{C}$ for $1 \mathrm{~min}$. Add $\operatorname{DMEM}(4 \mathrm{~mL})$ to the cells and re-suspend the cells by pipetting gently. Seed approximately $5 \times 10^{5}$ cells per dish into $35 \mathrm{~mm}$ glass bottom dishes in DMEM $(2 \mathrm{~mL}) 24 \mathrm{~h}$ before transfection.

2. For four dishes, in a $1.5 \mathrm{~mL}$ microcentrifuge tube, dilute the plasmid DNA (pcDNA3-Halo-EGFR, $14 \mu \mathrm{g}$ ) in the reduced serum medium (700 $\mu \mathrm{L})$. Separately, dilute the lipofection reagent $(5 \mu \mathrm{L})$ in the reduced serum medium $(150 \mu \mathrm{L})$ into each of four tubes and allow them stand at ambient temperature for 5 min.

3. Add a portion of the diluted plasmid DNA $(150 \mu \mathrm{L})$ to each of the diluted lipofection reagent samples. Incubate at ambient temperature for 5 $\min$.

4. After maintaining the cells at $37^{\circ} \mathrm{C}$ and $5 \% \mathrm{CO}_{2}$ for $24 \mathrm{~h}$, aspirate the DMEM and rinse the cells with phosphate-buffered saline (PBS, $2 \mathrm{~mL}$ ). Add the reduced serum medium $(1.5 \mathrm{~mL})$

5. Add the plasmid-lipofection reagent $(150 \mu \mathrm{L})$ complex to each dish. Maintain the cells at $37^{\circ} \mathrm{C}$ and $5 \% \mathrm{CO}_{2}$ for $48 \mathrm{~h}$.

6. Aspirate the medium, add a portion of freshly prepared DMEM $(1 \mathrm{~mL})$ containing $2 \mu \mathrm{M} \mathrm{paBhc}-\mathrm{hex}-\mathrm{FITC} / \mathrm{Halo}$, and incubate the cells at $37{ }^{\circ} \mathrm{C}$ and $5 \% \mathrm{CO}_{2}$ for $30 \mathrm{~min}$.

7. Aspirate the medium containing the caged compound and rinse the cells twice with PBS+ (1 mL per rinse) to remove any unbound compounds. Add the reduced serum medium $(500 \mu \mathrm{L})$ and incubate the cells at $37^{\circ} \mathrm{C}$ and $5 \% \mathrm{CO}_{2}$ for 30 min to remove the compounds that entered the cells. NOTE: PBS+ is phosphate-buffered saline supplemented with $2 \mathrm{mM} \mathrm{CaCl}_{2}$ and $1 \mathrm{mM} \mathrm{MgCl}_{2}$.

8. Remove the medium and rinse the cells twice with PBS $+(1 \mathrm{~mL})$. Add a portion of a medium (1 $\mathrm{mL})$ that does not contain phenol red. Record fluorescence images by laser scanning confocal fluorescence microscopy.

\section{Photomediated modulation of a kinase localization using a clickable caged compound}

NOTE: Prior to use, maintain the $\mathrm{CHO}-\mathrm{K} 1$ cells in Ham's $\mathrm{F}-12$ medium supplemented with $10 \% \mathrm{FBS}$ at $37{ }^{\circ} \mathrm{C}$ and $5 \% \mathrm{CO}_{2}$.

1. Prepare a $100 \times$ working solution $(1 \mathrm{mM})$ of paBhc-AA (5) in DMSO.

NOTE: A $10 \mathrm{mM}$ stock solution of the compound is prepared and stored in a freezer $\left(-20^{\circ} \mathrm{C}\right)$.

2. Seed approximately $5 \times 10^{5}$ cells per dish into $35 \mathrm{~mm}$ glass bottom dishes in DMEM $(2 \mathrm{~mL}) 24 \mathrm{~h}$ before transfection.

3. Transfect $\mathrm{CHO}-\mathrm{K} 1$ cells with a plasmid coding for GFP-DGKy $48 \mathrm{~h}$ before the uncaging experiments. NOTE: Transfection is performed according to steps $5.2-5.5$.

4. Replace the medium with a reduced serum medium $(2 \mathrm{~mL})$. Add the $100 \times$ paBhc-AA working solution $(20 \mu \mathrm{L})$ and incubate the cells at $37{ }^{\circ} \mathrm{C}$ and $5 \% \mathrm{CO}_{2}$ for between $5 \mathrm{~min}$ and $1 \mathrm{~h}$.

NOTE: The loading time depends on the compound employed.

5. Place the cells on the objective stage of an inverted fluorescent microscope equipped with a dual light source fluorescence illuminator.

6. Take a fluorescent image every $10 \mathrm{~s}$. Irradiate the cells with $330-385 \mathrm{~nm}$ light through a microscope objective for an appropriate time. Alternatively, irradiate the cells with $405 \mathrm{~nm}$ light using a Xe lamp through flexible quartz fibers.

7. Continue to record fluorescent images for $10 \mathrm{~min}$.

\section{Representative Results}

Clickable caged compounds of some biologically interesting molecules, including arachidonic acid and paclitaxel, were successfully synthesized

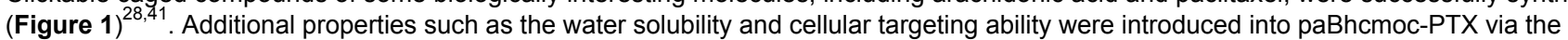
copper(I)-catalyzed Huisgen cyclization (“Click" reaction) (Figure 2). These clickable caged PTXs were then photolyzed to produce their parent PTXs upon irradiation at $350 \mathrm{~nm}$ (Figure 3), and the physical and photochemical properties of the clickable caged compounds are summarized in Table 1. The quantum yields of clickable caged compounds 2'-glc-paBhcmoc-PTX $\left(\Phi_{\text {dis }} 0.14\right)$ and paBhc-AA $\left(\Phi_{\text {dis }} 0.083\right)$ were more than twice those of conventional Bhc caged compounds 2 -Bhcmoc-PTX $\left(\Phi_{\text {dis }} 0.040\right)$ and Bhc-AA $\left(\Phi_{\text {dis }} 0.038\right)^{43}$. In addition, an improved water solubility was observed for 2'-glc-paBhcmoc-PTX, which contains a glucose moiety.

In live cell experiments, the targeting of paBhc-hex-FITC/Halo to the cultured mammalian cells transiently expressing a fusion protein of a HaloTag protein and epidermal growth factor receptor (EGFR) was achieved successfully. Green fluorescence of the fluorescein moiety of paBhc-hex-FITC/Halo was observed on the cell membrane (Figure 4). Photo-mediated modulation of the subcellular localization of a kinase was achieved using a paBhc caged compound. The translocation of diacylglycerol kinase $y$ (DGKy) has been reported to be activated in the presence of arachidonic acid (AA) ${ }^{44}$. CHO-K1 cells transiently expressing GFP-DGKy were treated with either AA or paBhc-AA (5). Addition of AA caused the modulation of the subcellular localization of DGKY (Figure 5A,B). Similar changes in the localization of DGKy were observed for the paBhcAA-treated cells after exposure to UV light (Figure 5C,D). 
A<smiles>Cc1cc(=O)oc2cc(O)c(Br)cc12</smiles>

$\mathrm{BhcCH}_{2} \mathrm{OH}$ (1)<smiles>O=c1cc(CO)c2cc(Br)c(O)cc2o1</smiles><smiles>C#CCN(C)Cc1c(O)c(Br)cc2c(CO)cc(=O)oc12</smiles>

paBhcCH ${ }_{2} \mathrm{OH}$ (2)

B

general procedure 1<smiles>C#CCN(C)Cc1c(O)c(Br)cc2c(COC(=O)n3ccnc3)cc(=O)oc12</smiles>

Boc-NH( $\left(\mathrm{CH}_{2}\right)_{6} \mathrm{NH}_{2}$

$$
\text { DMAP }
$$

$93 \%$ yield<smiles>C#CCN(C)Cc1c(O)c(Br)cc2c(COC(=O)NCCCCCCNC(=O)OC(C)(C)C)cc(=O)oc12</smiles>

general procedure 2<smiles>[R]OC(=O)[C@H](NC(=O)c1ccccc1)[C@@H](OC(=O)Oc1ccc([N+](=O)[O-])cc1)c1ccccc1</smiles>

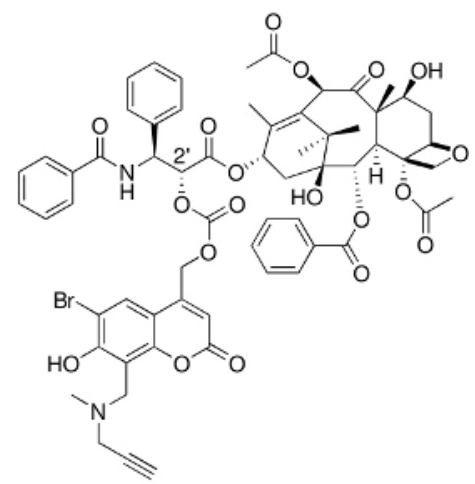

2'-paBhcmoc-PTX (4)

general procedure 3

$2+$ arachidonic acid

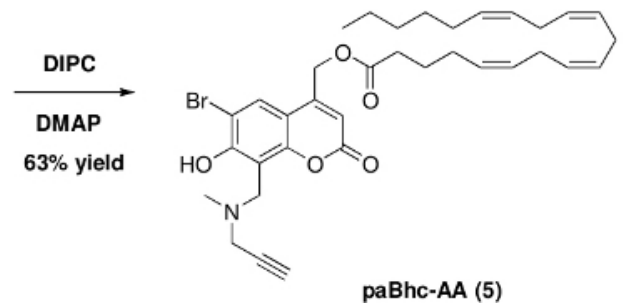

Figure 1: Preparation of the clickable caged compounds.

(A) Reagents and conditions: a. ethyl 4-chloroacetoacetate/conc. $\mathrm{H}_{2} \mathrm{SO}_{4} / \mathrm{rt} / 7$ days $/ 91 \%$ yield, b. $1 \mathrm{M} \mathrm{HCl} / \mathrm{reflux} / 3$ days $/ 97 \%$ yield. c.

$\mathrm{N}$-methylpropargylamine $/ \mathrm{HCHO} / \mathrm{EtOH}$, then add (1) and heat at reflux for $17 \mathrm{~h} / 79 \%$ yield. (B) Syntheses of the clickable caged amine, PTX, and arachidonic acid. Please click here to view a larger version of this figure. 
A<smiles>Oc1cc(O)c(O)c(O)c1</smiles>
$\mathrm{CuSO}_{4}$ MSO- $\mathrm{H}_{2} \mathrm{O}$

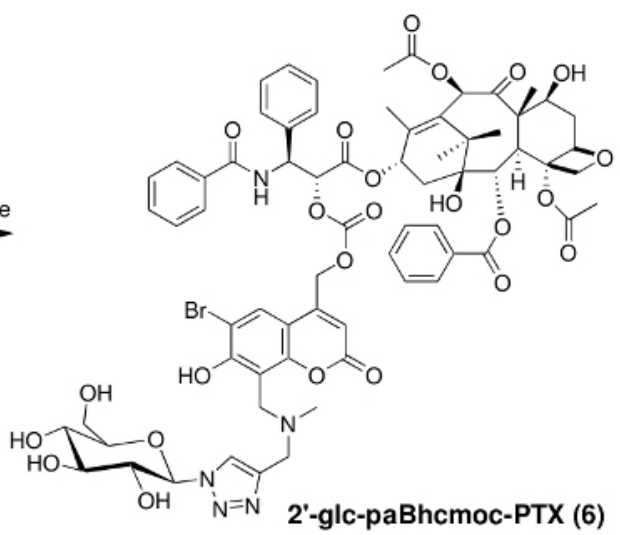

B

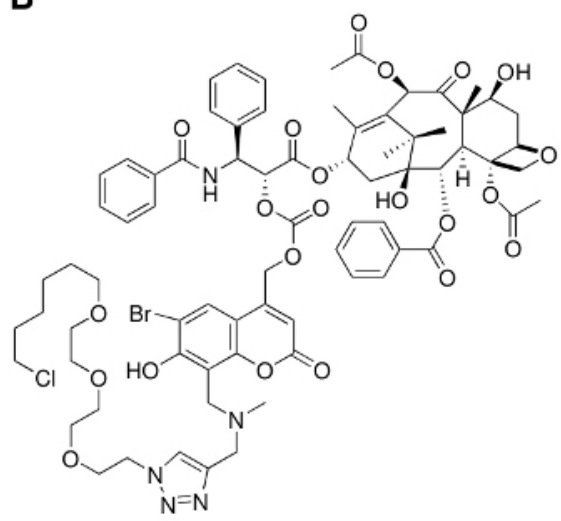

2'-Halo-paBhcmoc-PTX (7)

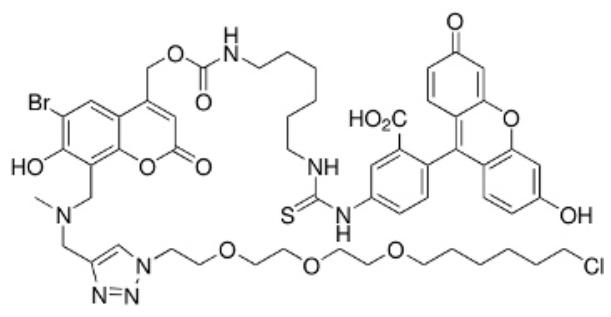

paBhc-hex-FITC/Halo (8)

Figure 2: Installation of functional units into clickable caged compounds.

(A) Synthesis of a water-soluble caged PTX via the copper(I)-catalyzed Huisgen cyclization. (B) Structures of clickable caged compounds containing the HaloTag ligand for cellular targeting. Please click here to view a larger version of this figure.

\section{A}

$\mathrm{RT}=4.2 \mathrm{~min}$

2'-Glc-paBhcmoc-PTX

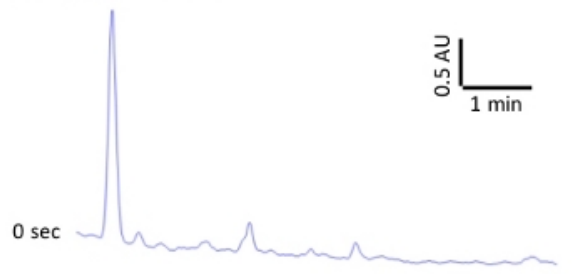

$\mathrm{RT}=10.3 \mathrm{~min}$

PTX
B

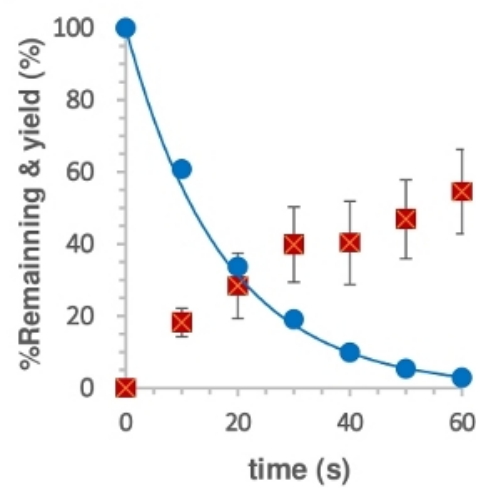

Figure 3: Photolysis of 2'-glc-paBhcmoc-PTX (6).

Samples $(10 \mu \mathrm{M})$ in K-MOPS solution ( $\mathrm{pH} \mathrm{7.2)}$ were irradiated at $350 \mathrm{~nm}$. (A) Typical HPLC traces for the photolysis of 6 (measured at $254 \mathrm{~nm}$ ). Samples were analyzed at the specified irradiation time. (B) Time course for the photolysis of 6 . Blue circles show the consumption of 6 . The solid line shows the least-squares curve fit for a simple decaying exponential for $\mathbf{6}$. Red squares show the yield of PTX. The error bars represent the standard deviation $( \pm S D)$. Please click here to view a larger version of this figure. 

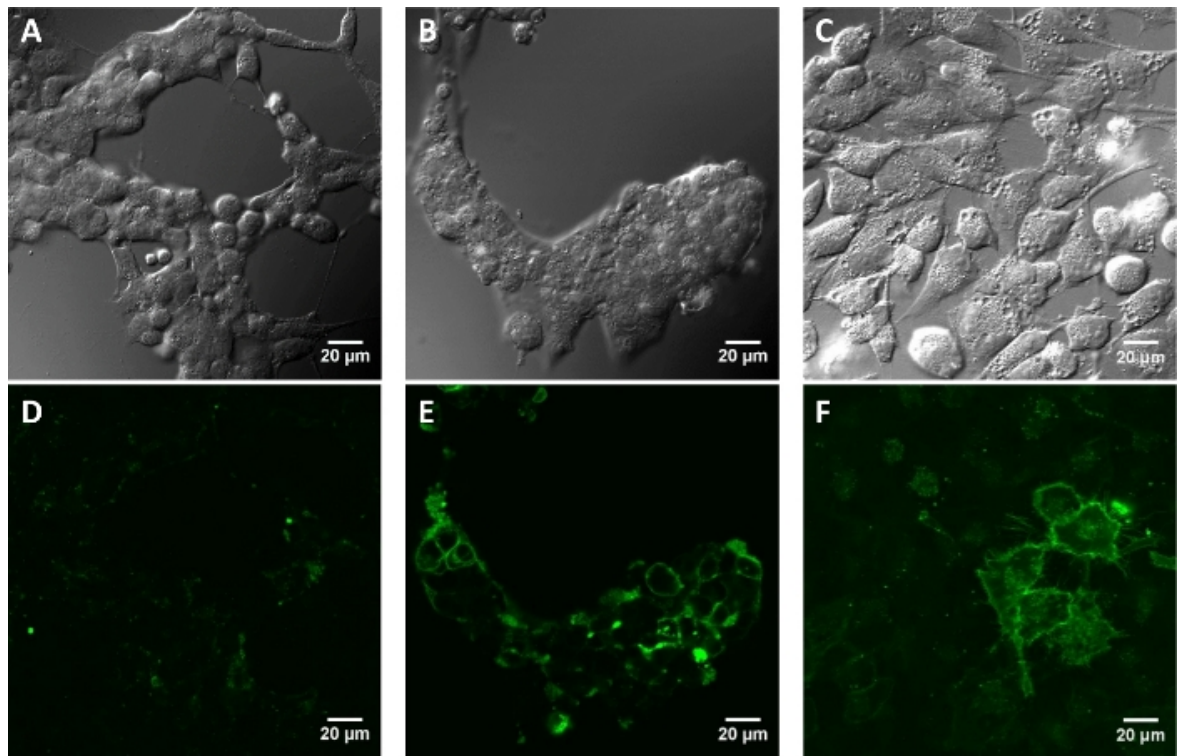

Figure 4: Fluorescence images of cultured mammalian cells incubated with paBhc-hex-FITC/Halo (8).

Cells transfected with pcDNA3-Halo-EGFR were incubated with a $2 \mu \mathrm{M}$ solution of compound 8 at $37^{\circ} \mathrm{C}$ for 30 min. The images were obtained after repeated washing with PBS+. Mock-treated HEK293T cells (A: differential interference contrast (DIC) image and D: fluorescence image). HEK293T cells (B and E) and HeLa cells (C and F) transiently expressing Halo-EGFR (B and C: DIC images and $\mathbf{E}$ and $\mathbf{F}$ : fluorescence images). Please click here to view a larger version of this figure.
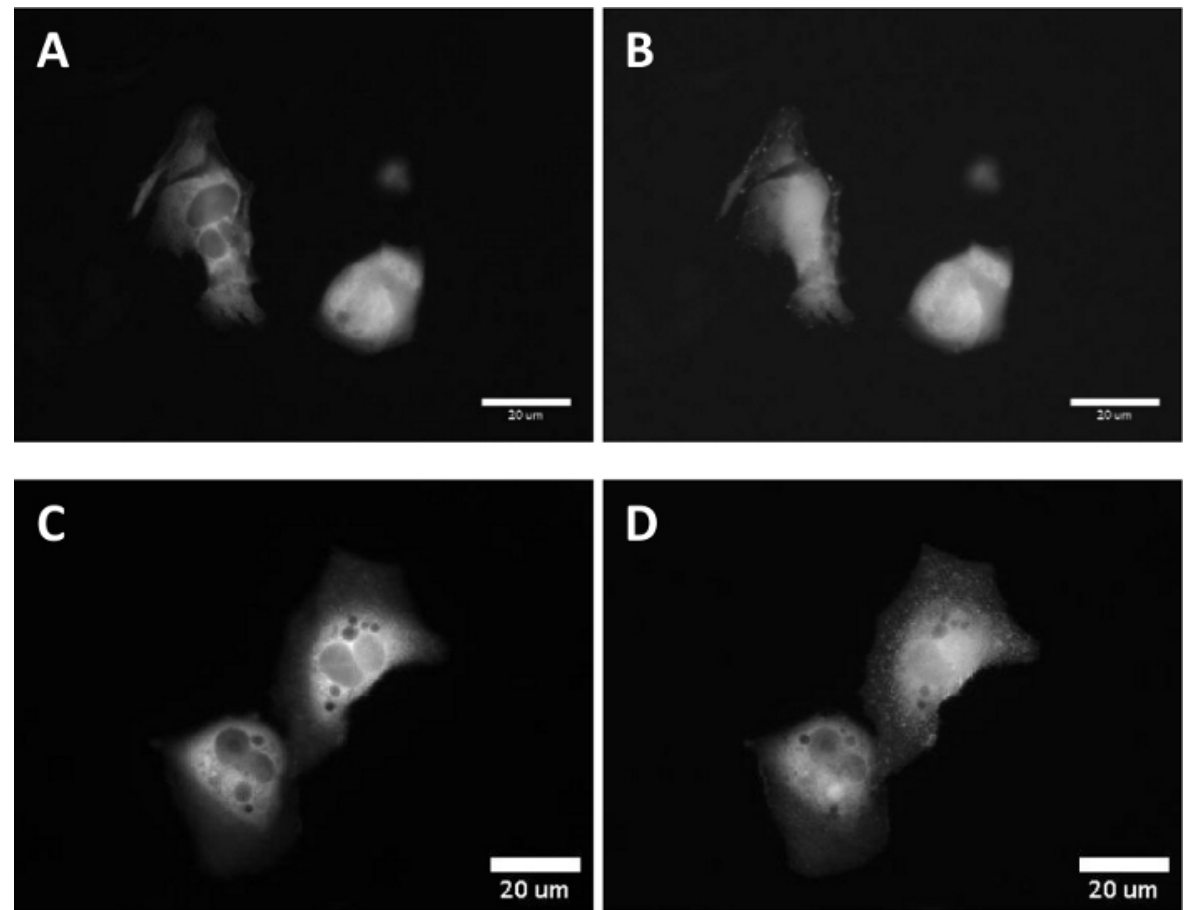

Figure 5: Fluorescence images after UV irradiation of the CHO-K1 cells incubated with Bhc caged arachidonic acid. CHO-K1 cells were transfected with a fusion protein DGKy-EGFP.

(A) A fluorescence image of the transfected cells. (B) $100 \mathrm{~s}$ after the addition of a $10 \mu \mathrm{M}$ solution of arachidonic acid. (C) Cells were incubated with a $10 \mu \mathrm{M}$ solution of paBhc-AA (5) at $37^{\circ} \mathrm{C}$ for $5 \mathrm{~min}$. (D) $100 \mathrm{~s}$ after 20 -s UV irradiation (330-385 nm). Please click here to view a larger version of this figure. 


\begin{tabular}{|l|l|l|l|l|l|}
\hline compounds & $\lambda_{\max }(\mathrm{nm})^{\mathrm{a}}$ & $\varepsilon_{\max }\left(\mathrm{M}^{-1} \mathrm{~cm}^{-1}\right)^{\mathrm{b}}$ & ${\phi_{\text {dis }}}^{\mathrm{c}}$ & $\varepsilon_{\phi_{\text {dis }}{ }^{\mathrm{d}}}$ & Solubility $(\mu \mathrm{M})^{\mathrm{e}}$ \\
\hline PTX & & & & & 1.0 \\
\hline $2^{\prime}-$ Bhcmoc-PTX & 340 & 10500 & 0.040 & 400 & 55 \\
\hline 2'-paBhcmoc-PTX & 359 & 9300 & 0.059 & 670 & 8.3 \\
\hline 2'-glc-Bhcmoc-PTX & 373 & 12300 & 0.14 & 1280 & 650 \\
\hline Bhc-AA & 341 & 10800 & 0.038 & 390 & \\
\hline paBhc-AA & 366 & 10300 & 0.083 & 750 & \\
\hline
\end{tabular}

Table 1: Physical and photochemical properties of the clickable caged compounds.

a. Absorption maximum (nm), b. Molar absorptivity at $\lambda_{\max }\left(\mathrm{M}^{-1} \mathrm{~cm}^{-1}\right)$, c. Quantum yield of the disappearance of the starting materials at 350 $\mathrm{nm}, \mathrm{d}$. The product of molar absorptivity and the quantum yield of disappearance at $350 \mathrm{~nm}$, e. The concentration of the saturated solution in KMOPS (pH 7.2) $\left(\mu \mathrm{g} \mathrm{mL}^{-1}\right)$.

\section{Discussion}

We previously developed Bhc caged compounds of various biologically active molecules that exhibit high photolytic efficiencies ${ }^{28,45,46,47}$. With the aim of expanding the repertoire of Bhc caging groups, we also reported platforms of modular caged compounds that can be modified easily by the introduction of various functional units ${ }^{32,40,41}$. The present protocol therefore represents a method for the synthesis of a clickable precursor of Bhc caging groups that can be modified via the copper(I)-catalyzed Huisgen cyclization. The synthesis of the clickable precursor, paBhcCH $\mathrm{OH}_{2}$ (2), was achieved via a four-step reaction sequence starting from the commercially available 4-bromoresorcinol (Figure 1A). The advantage of the present protocol is that no laborious purification steps (e.g., column chromatographic separations) are required.

As clickable precursor paBhcCH $\mathrm{H}_{2} \mathrm{OH}(2)$ can be used to mask various functional groups, clickable caged compounds of amines, alcohols, and carboxylic acids were synthesized using 2 as the precursor (Figure 1B). Amines were modified as their carbamates while alcohols were modified as their carbonates. In general procedures 1 and 2, CDI was used for the preparation of clickable carbamates, while 4-nitrophenyl chloroformate was used for the preparation of carbonates. As indicated by the reaction mechanism, both reagents can be used for the preparation of carbamates and carbonates. It should also be noted that the yield of the desired caged compound depends on the chemical structure of the molecule to be caged. Other examples can be seen in our previous reports ${ }^{28,30,33,48}$.

Click modification was then performed using a slight modification of the reported procedure ${ }^{49}$. The addition of tris(triazolylmethyl)amine-based ligands is necessary to obtain the desired products in good to high yields. Since a variety of azides are readily available both from commercial sources and from literature procedures, we can prepare various modular caged compounds with additional properties such as water solubility and cellular targeting ability (Figure 2).

The quantum yield of photolysis was then measured according to a reported procedure ${ }^{28,50}$. Figure 3 shows that the photolytic consumption of 2'-glc-paBhcmoc-PTX and the release of PTX were approximated by single-exponential decay and rise, respectively, suggesting no inner filtering of the radiation or undesired secondary effects. Improved photolysis quantum yields $(\Phi)$ and photolysis efficiencies $(\varepsilon \Phi)$ were observed for the clickable paBhc caged compounds compared to those of the previously reported Bhc caged compounds (Table 1$)^{41,43}$. Since the photolysis efficiencies $(\varepsilon \Phi)$ of Bhc caged compounds are more than one hundred times higher than those of 2-nitrobenzyl-type caged compounds ${ }^{4}$, the marked improvement due to the presence of paBhc caging groups is clearly an advantage for this system.

As a proof-of-concept experiment, a hydrophilic moiety was introduced into 2'-paBhcmoc-PTX (4) and a cellular targeting ligand was introduced into compound 3 (Figure 2). The water solubility of 2'-glc-paBhcmoc-PTX was 650 times higher than that of the parent PTX (Table 1). Selective cellular targeting was achieved using a tag-probe system, and paBhcmoc-hex-FITC/Halo (8) bearing the HaloTag ligand was successfully targeted to the cell membrane of cultured mammalian cells expressing the HaloTag/EGFR fusion protein (Figure 4). Photo-mediated modulation of the subcellular localization of a kinase was also achieved using a clickable caged compound $\mathbf{5}$ (Figure 5).

In conclusion, we successfully demonstrated a method for the preparation of clickable platforms for photo-caged compounds of biologically interesting molecules that can be modified easily with additional properties, such as water solubility and a cellular targeting ability. Since the paBhc caging group can be used to prepare any molecules with modifiable functional groups, the application of the present protocol is not limited to the molecules described herein. Using a modular platform, namely the paBhc caging group, the desired caged compounds can be easily prepared, and their physical and chemical properties can be modulated via click modification.

\section{Disclosures}

We have nothing to disclose.

\section{Acknowledgments}

This work was supported by JSPS KAKENHI grant number JP16H01282 (TF), a Grant-in-Aid for Scientific Research on Innovative Areas

"Memory Dynamism," and JP19H05778 (TF), "MolMovies." 


\section{References}

1. Mayer, G., Heckel, A., Biologically active molecules with a "light switch", Angewandte Chemistry International Edition. 45 (30), $4900-4921$ (2006).

2. Bort, G., Gallavardin, T., Ogden, D., Dalko, P. I., From One-Photon to Two-Photon Probes: "Caged" Compounds, Actuators, and Photoswitches. Angewandte Chemistry International Edition. 52 (17), 4526-4537 (2013).

3. Klan, P., et al., Photoremovable Protecting Groups in Chemistry and Biology: Reaction Mechanisms and Efficacy. Chemical Reviews. 113 (1), 119-191 (2013).

4. Abe, M., et al., Design and Synthesis of Two-Photon Responsive Chromophores for Near-Infrared Light-Induced Uncaging Reactions. Synthesis-Stuttgart. 49 (15), 3337-3346 (2017).

5. Ankenbruck, N., Courtney, T., Naro, Y., Deiters, A., Optochemical Control of Biological Processes in Cells and Animals, Angewandte Chemistry International Edition. 57 (11), 2768 (2018).

6. Hou, Y., Zhou, Z., Huang, K., Yang, H., Han, G., Long Wavelength Light Activated Prodrug Conjugates for Biomedical Applications, ChemPhotoChem. 2, 1005 (2018).

7. Engels, J., Schlaeger, E. J., Synthesis, structure, and reactivity of adenosine cyclic 3',5'-phosphate benzyl triesters, Rapid photolytic release of adenosine 5'-triphosphate from a protected analogue: utilization by the Na:K pump of human red blood cell, Journal of Medicinal Chemistry. 20 (7), 907-911 (1977)

8. Kaplan, J. H., Forbush III, B., Hoffman, J. F., Rapid photolytic release of adenosine 5'-triphosphate from a protected analogue: utilization by the Na:K pump of human red blood cell ghosts Biochemistry. 17 (10), 1929-1935 (1978).

9. Park, C.-H., Givens, R. S., New Photoactivated Protecting Groups. 6. p-Hydroxyphenacyl: A Phototrigger for Chemical and Biochemical Probes, Journal of the American Chemical Society. 119 (10), 2453-2463 (1997).

10. Hasan, A., et al., Photolabile protecting groups for nucleosides: synthesis and photo-deprotection rates, Tetrahedron. 53 (12), $4247-4264$ (1997).

11. Heckel, A., Mayer, G., Light regulation of aptamer activity: an anti-thrombin aptamer with caged thymidine nucleobases, Journal of the American Chemical Society. 127 (3), 822-823 (2005).

12. Papageorgiou, G., Corrie, J. E. T., Effects of aromatic substituents on the photocleavage of 1-acyl-7-nitroindolines, Tetrahedron. 56 (41), 8197-8205 (2000).

13. Matsuzaki, M., Ellis-Davies, G. C., Nemoto, T., Miyashita, Y., lino, M., Kasai, H., Dendritic spine geometry is critical for AMPA receptor expression in hippocampal CA1 pyramidal neurons, Nature Neuroscience. 4 (11), 1086-1092 (2001).

14. Givens, R. S., Matuszewski, B., Photochemistry of phosphate esters: an efficient method for the generation of electrophiles, Journal of the American Chemical Society. 106 (22), 6860-6861 (1984).

15. Furuta, T., Torigai, H., Sugimoto, M., Iwamura, M., Photochemical Properties of New Photolabile cAMP Derivatives in a Physiological Saline Solution, Journal of Organic Chemistry. 60 (13), 3953-3956 (1995).

16. Hagen, V., Frings, S., Wiesner, B., Helm, S., Kaupp, U. B., Bendig, J., [7-(Dialkylamino)coumarin-4-yl]methyl-Caged Compounds as Ultrafast and Effective Long-Wavelength Phototriggers of 8-Bromo-Substituted Cyclic Nucleotides. ChemBioChem. 4 (5), 434-442 (2003).

17. Momotake, A., Lindegger, N., Niggli, E., Barsotti, R. J., Ellis-Davies, G. C., The nitrodibenzofuran chromophore: a new caging group for ultraefficient photolysis in living cells. Nature Methods. 3 (1), 35-40 (2006).

18. Specht, A., et al., New photoremovable protecting groups for carboxylic acids with high photolytic efficiencies at near-UV irradiation. Application to the photocontrolled release of L-glutamate. ChemBioChem. 7 (11), 1690-1695 (2006).

19. Petersen, S., Alonso, J. M., Specht, A., Duodu, P., Goeldner, M., del Campo, A., Phototriggering of cell adhesion by caged cyclic RGD peptides. Angewandte Chemistry International Edition. 47 (17), 3192-3195 (2008).

20. Heckman, L. M., et al., Design and Synthesis of a Calcium-Sensitive Photocage. Angewandte Chemistry International Edition. 55 (29), 8363-8366 (2016).

21. Olson, J. P., Banghart, M. R., Sabatini, B. L., Ellis-Davies, G. C., Spectral Evolution of a Photochemical Protecting Group for Orthogonal TwoColor Uncaging with Visible Light, Journal of the American Chemical Society. 135 (42), 15948-15954 (2013).

22. Gandioso, A., et al., Sequential Uncaging with Green Light can be Achieved by Fine-Tuning the Structure of a Dicyanocoumarin Chromophore, ChemistryOpen. 6 (3), 375-384 (2017).

23. Bassolino, G., Nancoz, C., Thiel, Z., Bois, E., Vauthey, E., Rivera-Fuentes, P., Photolabile coumarins with improved efficiency through azetidinyl substitution. Chemical Science. 9 (2), 387-391 (2018).

24. Lin, Q. N., et al., Coumarin Photocaging Groups Modified with an Electron-Rich Styryl Moiety at the 3-Position: Long-Wavelength Excitation, Rapid Photolysis, and Photobleaching. Angewandte Chemistry International Edition. 57 (14), 3722-3726 (2018).

25. Nani, R. R., et al., In Vivo Activation of Duocarmycin-Antibody Conjugates by Near-Infrared Light. ACS Central Science. 3 (4), $329-337$ (2017).

26. Umeda, N., et al. Boron Dipyrromethene As a Fluorescent Caging Group for Single-Photon Uncaging with Long-Wavelength Visible Light. ACS Chemical Biology. 9 (10), 2242-2246 (2014).

27. Slanina, T., et al., In Search of the Perfect Photocage: Structure-Reactivity Relationships in meso-Methyl BODIPY Photoremovable Protecting Groups. Journal of the American Chemical Society. 139 (42), 15168-15175 (2017).

28. Furuta, T., et al., Brominated 7-hydroxycoumarin-4-ylmethyls: Photolabile protecting groups with biologically useful cross-sections for two photon photolysis. Proceedings of the National Academy of Sciences of the United States of America. 96 (4), 1193-1200 (1999).

29. Furuta, T., et al., Bhc-cNMPs as either water-soluble or membrane-permeant photoreleasable cyclic nucleotides for both one- and two-photon excitation. ChemBioChem. 5 (8), 1119-1128 (2004).

30. Suzuki, A. Z., et al., Coumarin-4-ylmethoxycarbonyls as phototriggers for alcohols and phenols. Organic Letters. 5 (25), $4867-4870$ (2003).

31. Ando, H., Furuta, T., Tsien, R. Y., Okamoto, H., Photo-mediated gene activation using caged RNA/DNA in zebrafish embryos. Nature Genetics. 28 (4), 317-325 (2001).

32. Teraoka, A., Murakoshi, K., Fukamauchi, K., Suzuki, A. Z., Watanabe, S., Furuta, T., Preparation and affinity-based purification of caged linear DNA for light-controlled gene expression in mammalian cells. Chemical Communications. 50 (6), 664-666 (2014). 
33. Watanabe, T., et al., Synthesis of nucleobase-caged peptide nucleic acids having improved photochemical properties. Organic and Biomolecular Chemistry. 12 (28), 5089-5093 (2014).

34. Horinouchi, T., Nakagawa, H., Suzuki, T., Fukuhara, K., Miyata, N., A novel mitochondria-localizing nitrobenzene derivative as a donor for photo-uncaging of nitric oxide. Bioorganic \& Medicinal Chemistry Letters. 21 (7), 2000-2002 (2011).

35. Leonidova, A., et al., Photo-induced uncaging of a specific Re(I) organometallic complex in living cells. Chemical Science. 5 (10), $4044-4056$ (2014).

36. Nadler, A., et al., Exclusive photorelease of signalling lipids at the plasma membrane. Nature Communications. 6, 10056 (2015).

37. Feng, S. H., et al., Mitochondria-specific photoactivation to monitor local sphingosine metabolism and function. Elife. 7, e34555 (2018).

38. Wagner, N., Stephan, M., Hoglinger, D., Nadler, A., A Click Cage: Organelle-Specific Uncaging of Lipid Messengers. Angewandte Chemistry International Edition. 57 (40), 13339-13343 (2018).

39. Feng, S., Harayama, T., Chang, D., Hannich, J. T., Winssinger, N., Riezman, H., Lysosome-targeted photoactivation reveals local sphingosine metabolism signatures. Chemical Science. 10 (8), 2253-2258 (2019).

40. Furuta, T., Manabe, K., Teraoka, A., Murakoshi, K., Ohtsubo, A., Suzuki, A., Design, synthesis, and photochemistry of modular caging groups for photoreleasable nucleotides. Organic Letters. 14 (24), 6182-6185 (2012).

41. Suzuki, A. Z., et al., A clickable caging group as a new platform for modular caged compounds with improved photochemical properties. Chemical Communications. 55 (4), 451-454 (2019).

42. Hatchard, C. G., Parker, C. A., A new sensitive chemical actinometer - II. Potassium ferrioxalate as a standard chemical actinometer, Proceedings of the Royal Society A. 235 (1203), 518-536 (1956).

43. Furuta, T., Nishiyama, K., Manabe, A., Fukuoka, M., Iwamura, M, Design, synthesis and photochemical properties of caged compounds of lipid mediators, Proceedings of the ISBC. 2003, 124-125 (2003).

44. Shirai, Y., Segawa, S., Kuriyama, M., Goto, K., Sakai, N., Saito, N., Subtype-specific Translocation of Diacylglycerol Kinase $\alpha$ and $y$ and Its Correlation with Protein Kinase C. The Journal of Biological Chemistry. 275 (32), 24760-24766 (2000).

45. Furuta, T., Noguchi, K., Controlling cellular systems with Bhc-caged compounds. TrAC, Trends in Analytical Chemistry. 23 (7), 511-519 (2004).

46. Furuta, T., Designing caged compounds for spatiotemporal control of cellular chemistry. Journal of the Synthetic Organic Chemistry Japan. 69 (11), 1164-1169 (2012).

47. Furuta, T., Coumarin-4-ylmethyl Phototriggers. In Dynamic Studies in Biology: Phototriggers, Photoswitches and Caged Biomolecules, Goeldner, M.; Givens, R. S., Eds. 29-55, WILEY-VCH (2005).

48. Furuta, T., Watanabe, T., Tanabe, S., Sakyo, J., Matsuba, C., Phototriggers for Nucleobases with Improved Photochemical Properties. Organic Letters. 9 (23), 4717-4720 (2007).

49. Manova, R., van Beek, T. A., Zuilhof, H., Surface Functionalization by Strain-Promoted Alkyne-Azide Click Reactions. Angewandte Chemistry International Edition. 50 (24), 5428-5430 (2011).

50. Adams, S. R., Kao, J. P. Y., Grynkiewicz, G., Minta, A., Tsien, R. Y., Biologically Useful Chelators That Release Ca2+ Upon Illumination. Journal of the American Chemical Society. 110 (10), 3212-3220 (1988). 